\title{
Migration and Time: Duration as an Instrument to Welcome or Restrict
}

\author{
Gerrie Lodder*
}

\section{Abstract}

States apply different material conditions to attract or restrict residence of certain types of migrants. But states can also make use of time as an instrument to design more welcoming or more restrictive policies. States can apply faster application procedures for desired migrants. Furthermore, time can be used in a more favourable way to attract desired migrants in regard to duration of residence, access to a form of permanent residence and protection against loss of residence. This contribution makes an analysis of how time is used as an instrument in shaping migration policy by the European Union (EU) legislator in the context of making migration more or less attractive. This analysis shows that two groups are treated more favourably in regard to the use of time in several aspects: EU citizens and economic- and knowledge-related third-country nationals. However, when it comes to the acquisition of permanent residence after a certain period of time, the welcoming policy towards economic- and knowledge-related migrants is no longer obvious.

Keywords: Migration, EU migration law, time

\section{Introduction}

Migration can be defined very broadly as the movement from one place to another. But from a legal perspective, migration is generally understood as the movement from one state to another. Leaving a state, including the state of a person's own nationality, is a universally recognised right, laid down in the Universal Declaration of Human Rights, ${ }^{1}$ and later transposed into numerous other human rights instruments. The other side of the coin - entering another country - is less clearly regulated. The right to enter another country touches upon state sovereignty and upon the right of states to decide who belongs to their population and has a right to enter and stay. In making policies and laws in regard to regulating migration, states make a distinction between migrants to whom they have to give access to the territory and a right to stay, migrants who they welcome to enter and stay, and migrants towards whom states are less welcoming.

Gerrie Lodder is lecturer and researcher at the Europa Institute of Leiden University.

1. Art. 13(2)
States apply different material conditions for different categories to attract or restrict residence of certain types of migrants. But states can also make use of time as an instrument to design more welcoming or more restrictive policies: time to wait in application procedures, a period of time for entitlement to certain rights such as a right to permanent residence or citizenship, or time as a protection against loss of residence rights. An illustrious example of the use of time in a welcoming way is the accelerated naturalisation of the current Queen Maxima in the Netherlands, who acquired Dutch nationality six weeks after her engagement to Willem-Alexander where the normal rules require at least three years of marriage and living together with a Dutch citizen.

Several authors have explored the relationship between time and migration in general ${ }^{2}$ or migration law more specifically. Stronks looks from a legal and philosophical perspective into the meaning of time in the incremental system of residence entitlements in European migration law. ${ }^{3}$ He concludes that the hypothesis that migrants receive stronger rights the longer they stay in a country is partly true, but does not provide an answer to the question as to why some receive stronger rights over time. Motomura researched the implications of growing (family) ties over time for firmer rights. ${ }^{4}$ Carens addresses the question of temporary admission from a moral perspective, and argues that democratic states cannot keep people indefinitely in a 'temporary' status. ${ }^{5}$ Other authors focused on time used as a tactic to deter the migration of migrants who are not really wanted. Eule et al. provide numerous examples of how states make use of time in this way. ${ }^{6}$ The options in EU legis-

2. See for an exploration of topics and publications: Griffiths M., Rogers A., Anderson B. (2013) Migration, Time and Temporalities: Review and Prospect, COMPAS Research Resources Paper, March 2013. See also: Griffiths M.B.E. (2014) Out of Time: The Temporal Uncertainties of Refused Asylum Seekers and Immigration Detainees, Journal of Ethnic and Migration Studies, Volume 40, Issue 2, p. 12.

3. Stronks M. (2017) Grasping Legal Time. A Legal and Philosophical Analysis of the Role of Time in European Migration Law.

4. Motomura H. (2006) We Asks for Workers but Families Came: Time, Law and the Family in Immigration and Citizenship, Virginia Journal of Social Policy \& the Law. Volume 13, pp. 239-254.

5. Carens H.C. (2013) The Ethics of Immigration. New York: Oxford University Press, p. 113.

6. Eule T.G., Borrelli L.M., Lindberg A., Wyss A. (2019) Time as Waste and Tactic. In: Eule T.G., Borrelli L.M., Lindberg A., Wyss A., Migrants before the Law: Contested Migration Control in Europe. Cham: Palgrave Macmillan. 
lation on acceleration of the asylum procedures have been debated by several authors. ${ }^{7}$

This article aims to contribute to the existing literature by combining these elements - time used to restrict or facilitate entry and the role of time in granting stronger entitlements - in the context of developing policies to attract or restrict residence of certain categories of migrants. The article starts with the hypothesis that states apply faster application procedures for desired migrants. Furthermore, it is expected that time is used in a more favourable way to attract desired migrants in regard to duration of residence, access to a form of permanent residence and protection against loss of residence.

The sovereignty of states to develop migration policies is limited by international law. Most important is the prohibition to send a person back to a country where he fears persecution, where his life is threatened or where he risks torture or inhuman or degrading treatment, the so-called prohibition of refoulement. ${ }^{8}$ Furthermore, the widely recognised right to family life ${ }^{9}$ might, under certain circumstances, lead to a right of residence in a host state. However, besides these international obligations, migration law in the $\mathrm{EU}$ is for a large extent defined on a community level. Member States are bound by these rules and have limited sovereignty to develop national policies. For this reason, the analysis of migration law at the EU level is chosen in this article. However, some examples of the way the Member States apply the EU legislation and use the national discretion to develop their own rules will be provided.

In the next section, I will provide a short outline of the current body of EU migration law. This section is followed by some elaboration on the use of the concept of desired and less desired migrants. Subsequently, Section 4 looks at the time frame for application procedures. In Section 5, the differences in duration of residence are explored. Section 6 elaborates on the use of duration of residence for residence entitlements. Section 7 discusses in what way in EU law the length of stay can offer protection against loss of residence rights. A conclusion is formulated in the final section.

7. See, for example, Reneman M. (2013) Speedy Asylum Procedures in the EU: Striking a Fair Balance Between the Need to Process Asylum Cases Efficiently and the Asylum Applicant's EU Right to an Effective Remedy, International Journal of Refugee Law, Volume 25, Issue 4, pp. 717-48; Costello C., Hancox E. (2016) The Recast Asylum Procedures Directive 2013/32/EU: Caught between the Stereotypes of the Abusive Asylum Seeker and the Vulnerable Refugee. In: Chetail V., De Bruycker P., and Maiani F., Reforming The Common European Asylum System: The New European Refugee Law. Boston: Brill Nijhof.

8. See Art. 33 of the Geneva Refugee Convention of 1951, Art. 3 of the Convention against Torture, Art. 7 of the International Covenant on Civil and Political Rights (ICCPR) and Art. 3 of the European Convention on Human Rights (ECHR).

9. See, for example, Art. 17 ICCPR and Art. 8 ECHR.

\section{The EU Legal Framework}

EU migration law encompasses the regulation of both intra-EU migration as well as the migration of so-called third-country nationals (TCNs) - persons with a nonEU nationality - from outside the EU to the EU. Since the Amsterdam Treaty ${ }^{10}$ entered into force in 1999, the body of EU migration law related to this latter category has grown significantly. Nowadays, the EU legal framework for TCNs encompasses various rules: for admission to the EU territory; for the acquisition of a residence right; and, finally, for returning TCNs whose stay on EU territory is irregular.

The Schengen Border Code ${ }^{11}$ lays down the conditions for admission to the EU territory for a short stay of maximum ninety days. The relevant instrument for admission that will be discussed in this contribution is the Visa Code $^{12}$ (VC) which provides procedural rules for the acquisition of a visa for short stay. Important instruments in the field of asylum are the Qualification Directive $^{13}$ (QD), which sets rules for classifying an asylum seeker as a refugee or a person in need of other forms of international protection, and the Procedures Directive $^{14}$ (PD), which contains norms for application procedures. Of additional relevance is the Dublin Regulation $^{15}$ (DR), which lays down criteria to determine which Member State is responsible for the assessment of an asylum request. Family reunification is regulated in the Family Reunification Directive ${ }^{16}$ (FRD), which contains conditions for family reunification as well as procedural rules and rights for family members. In 2016, a revised directive entered into force which provides rules on several types of residence of which researchers and students are the most important, further referred to as the Researchers and Students Directive ${ }^{17}$ (RSD). Other categories of stay which are regulated in

10. Treaty of Amsterdam amending the Treaty on European Union, the Treaties establishing the European Communities and certain related acts.

11. Regulation (EU) $2016 / 399$ of the European Parliament and of the Council of 9 March 2016 on a Union Code on the rules governing the movement of persons across borders.

12. Regulation (EC) No 810/2009 of the European Parliament and of the Council of 13 July 2009 establishing a Community Code on Visas.

13. Directive 2011/95/EU of the European Parliament and of the Council of 13 December 2011 on standards for the qualification of third-country nationals or stateless persons as beneficiaries of international protection, for a uniform status for refugees or for persons eligible for subsidiary protection, and for the content of the protection granted.

14. Directive 2013/32/EU of the European Parliament and of the Council of 26 June 2013 on common procedures for granting and withdrawing international protection.

15. Regulation (EU) no 604/2013 of the European Parliament and of the Council of 26 June 2013 establishing the criteria and mechanisms for determining the Member State responsible for examining an application for international protection lodged in one of the Member States by a third-country national or a stateless person (recast).

16. Council Directive 2003/86/EC of 22 September 2003 on the right to family reunification.

17. Directive (EU) $2016 / 801$ of the European Parliament and of the Council of 11 May 2016 on the conditions of entry and residence of third-country nationals for the purposes of research, studies, training, voluntary service, pupil exchange schemes or educational projects and au pairing. 
this directive are au pairs, volunteers, pupil exchange schemes and trainees. In the field of economic migration, a system which consists of a general framework directive and three instruments to regulate a certain category of labour has been gradually developed. The general framework is regulated in the Single Permit Directive $^{18}$ (SPD), which contains procedural rules for all work-related migration application procedures and rights for migrant workers. The three instruments are the Blue Card Directive ${ }^{19}$ (BCD), which regulates the admission and rights of knowledge workers, the Seasonal Workers Directive ${ }^{20}$ (SWD) and the Intra Corporate Transfer Directive ${ }^{21}$ (ICTD). Finally, rules for a right to permanent residence are established in the LongTerm Residence Directive ${ }^{22}$ (LTRD). Residence based on this Directive is no longer determined by the purpose-related types of residence mentioned earlier. The rules for admission of asylum seekers, and to a lesser extent of family migrants, are influenced by the international legal standards mentioned earlier. The EU legal system in these areas leaves Member States with very limited sovereignty to develop their own policies. Member States are bound to grant a residence right to asylum- and family migrants who fulfil the criteria. This is different for economic, knowledge and cultural exchange-related migration. The legislation in these areas was developed to stimulate these types of migration, but Member States were rather reluctant to transfer sovereignty to the EU. ${ }^{23}$ This has resulted in a system where Member States remain free to decide on actual admission, with the exception of students. If a student fulfils the criteria of the Directive, Member States are bound to admit this student.

The rules for EU citizens moving to another Member State have gradually developed throughout the different stages of the EU integration process. Nowadays, EU citizens have the right to stay in the territory of another Member State for a maximum period of three months, with the sole requirement of being in possession of a valid passport or identity card. This right is also applicable to the TCN family member of a Union citizen who accompanies or joins the EU citizen. Some additional conditions apply in the case of residence longer

18. Directive 2011/98/EU of the European Parliament and of the Council of 13 December 2011 on a single application procedure for a single permit for third-country nationals to reside and work in the territory of a Member State and on a common set of rights for third-country workers legally residing in a Member State.

19. Council Directive 2009/50/EC of 25 May 2009 on the conditions of entry and residence of third-country nationals for the purposes of highly qualified employment

20. Directive 2014/36/EU of the European Parliament and of the Council of 26 February 2014 on the conditions of entry and stay of third-country nationals for the purpose of employment as seasonal workers.

21. Directive 2014/66/EU of the European Parliament and of the Council of 15 May 2014 on the conditions of entry and residence of third-country nationals in the framework of an intra-corporate transfer.

22. Council Directive 2003/109/EC of 25 November 2003 concerning the status of third-country nationals who are long-term residents.

23. Boeles P., Heijer, den M., Lodder G., Wouters K. (2014) European Migration Law, Cambridge - Antwerp - Portland: Intersentia (2nd revised edition), p. 157. than three months. In contrast to the strongly differentiated system of directives for TCNs, most rules in regard to residence for EU citizens and their family members are laid down in one Directive: the Free Movement Directive $^{24}$ (FMD). This Directive also regulates the residence for short stay - a stay of up to five years for workers, self-employed persons, students and economically non-active EU citizens - and permanent residence.

\section{Desired and Less Desired Migrants}

Policy makers, politicians, academics, society, we all try to construct categories to make sense of migration. ${ }^{25}$ Categories are often formulated in dichotomies: ${ }^{26}$ forced migration versus voluntary migration or refugees versus economic migrants; intra-EU migration of EU citizens versus migration of TCNs towards the EU; short-term migration versus permanent migration. Categorisation can be based on the place that migration occurs, the causes of movement and the time or duration of migration. ${ }^{27}$ In this article additional labels are used, namely the distinction between desired and less desired migration. The distinction between desired and less desired migrants - which is of course, as most categorisations, an oversimplification of reality - is used to evaluate the use of time by the EU legislator. To be able to function as an analytical tool, some clarification is needed of the way these concepts are used.

First is the question of which migrants are allegedly desired or non-desired. EU Member States display different views to the desirability of various types of migration. Also, within a state views on desirability will vary widely. However, this article is written from the perspective of the EU legislator. This means that the question of the desirability is approached from the EU perspective. Second, the desirability is not always easy to assess. Also at EU level frictions about migration policies exist between the different $\mathrm{EU}$ institutions involved in the process of making legislation. This results in compromises and ambiguity towards the desirability of a certain form of migration. A good example is the wording of the FRD. According to the preamble, family reunification

helps to create sociocultural stability facilitating the integration of third country nationals in the Member State, which also serves to promote economic and

24. Directive 2004/38/EC of the European Parliament and of the Council of 29 April 2004 on the right of citizens of the Union and their family members to move and reside freely within the territory of the Member States.

25. Crawley H., Skleparis D. (2018) Refugees, Migrants, Neither, Both: Categorical Fetishism and the Politics of Bounding in Europe's 'Migration Crisis', Journal of Ethnic and Migration Studies, Volume 44, Issue 1, pp. 50-51.

26. See, for example, Althaus A. (2016) The False Dichotomy between 'Economic Migrants' and Refugees, IOM, int.

27. Crawley, Skleparis (2018), pp. 50-51. 
social cohesion, a fundamental Community objective stated in the Treaty. ${ }^{28}$

This formulation suggests family reunification is a desired category of migration. However, at the time of the negotiations and after the implementation, many Member States tried to preserve to maintain as much as possible their national rules, to be able to control and restrict family migration. ${ }^{29}$ Finally, the desirability can change over time, due to changing circumstances or a different political climate ${ }^{30}$ For the purpose of this article, free movement of EU citizens will be regarded as desired migration as free movement of persons is one of the cornerstones of the EU. Economic and knowledge migration of TCNs can also be considered as welcome migration. ${ }^{31}$ Furthermore, short-term stay is regarded as desired migration, as follows from the proposal to reform the VC: "the vast majority of visa applicants pose no security and/or migratory risk to the EU and are bringing significant benefits to the EU'.32 At the same time it is recognised that 'migration and security issues become increasingly important'. ${ }^{33}$ As discussed earlier, the attitude towards family migration is ambiguous. However considering the stance of the Member States in the Council during the negotiations, it can be considered less desired migration. Finally, asylum migration is considered less desired, especially during the stage when it is not yet established whether or not an asylum applicant is entitled to international protection. However, regarding persons entitled to international protection, the EU is 'open to those who, forced by circumstances, legitimately seek protection in the Union'. ${ }^{34}$

\section{Application Procedures}

The length of an application procedure can be considered as an instrument for making migration more attractive, or less attractive. Lengthy application procedures can deter migrants from applying, while fast application procedures can make migration more attractive. ${ }^{35}$ At the same time, accelerated procedures and quick (negative)

28. Preamble 4 Directive 2003/86/EC.

29. See, for example, Groenendijk K. (2006) Family Reunification as a Right under Community Law, European Journal of Migration and Law, Volume 8, Issue 2, pp. 215-30. See also Lodder G.G. (2018) Richtlijn 2003/86/EG inzake het recht op gezinshereniging. In: Pahladsingh A. (ed.), Sdu Commentaar Europees Migratierecht. Den Haag: Sdu (editie 2018).

30. A good example is the 'Wir schaffen das' expression of German Prime Minister Angela Merkel and the subsequent developments. See e.g.: https://duitslandinstituut.nl/artikel/39507/vijf-jaar-na-wir-schaffendas.

31. See, for example, Communication from the Commission. Policy Plan on Legal Migration, $\operatorname{COM(2005)} 669$ final and preamble 8 and 14 Directive 2016/801/EU.

32. Proposal for a Regulation of the European Parliament and of the Council amending Regulation (EC) No 810/2009 establishing a Community Code on Visas (Visa Code), $\operatorname{COM(2018)~} 252$ final, p. 1

33. Ibid

34. Preamble 2 Directive 2011/95/EU.

35. Eule et al., 2019. decisions can discourage asylum seekers in particular from applying for asylum. ${ }^{36}$ In EU TCN migration law, all the instruments which regulate access to the territory of the EU or a right to a certain type of residence provide for time limits for concluding an application procedure. In analysing these time limits, an obvious division can be observed between labour-related and knowledgerelated migration on the one hand, and asylum and family migration on the other hand. In the case of labourrelated migration, the general norm is set in the SPD. In this Directive, the time limit for taking a decision on a combined application for a work permit and residence right is set at four months after the application has been lodged. Due to the complexity of the examination, this period can be prolonged with an undefined period. In separate work-related directives, the limit is even shorter. In the case of knowledge workers, intra-corporate transferees, seasonal workers, researchers, au pairs, volunteers and students, the time limit is ninety days. For researchers, volunteers and intra-corporate transferees, the respective Directives provide for the option of an even shorter time limit. In the proposal for a recast of the BCD, the time frame to make a decision on the application is shortened to sixty days, with the option of an accelerated procedure in thirty days. ${ }^{37}$ The Netherlands is an example where time frames of two weeks for application procedures for admission of economic and knowledge migrants of recognised sponsors are introduced, to attract some preferred categories of migrants. $^{38}$

On the other hand, the time frames for handling an application for family reunification and asylum are much longer. The longest time limit applies for family reunification applications: Member States have to make a decision within nine months after the application has been lodged. In exceptional circumstances, this time limit can be extended with an undefined period of time. ${ }^{39}$ However, in the case of family members of several categories of knowledge-related and labour-related migration, shorter time frames apply. In the case of applications of family members of knowledge workers a time limit of six months applies, while for the family members of inter-corporate transferees and researchers, the time limit is the same as for ICT workers (ninety days) or researchers (sixty days).

In the case of asylum seekers, the standard is set at six months. The PD provides for a prolongation of the time limit, with a maximum of nine months where a complex situation is involved, when large numbers of TCNs are applying or if the delay in the examination is wholly

36. Reneman M. (2016) Versnelling, verlenging en vereenvoudiging van asielprocedures vanwege hoge instroom. Spanning met het Europese recht, Asiel \& Migrantenrecht, Issue 6/7, p. 264.

37. Art. 10, Proposal for a Directive of the European Parliament and of the Council on the conditions of entry and residence of third-country nationals for the purposes of highly skilled employment, $\operatorname{COM(2016)}$ 378 final.

38. See the legal history of the Modern Migration Policy Act, e.g. TK 2009/10, 32 052, no. 7, pp. 2-3.

39. Art. 5(4) Directive 2003/86/EC. 
attributable to the applicant. ${ }^{40}$ However, the Directive also provides for the option to apply accelerated procedures ${ }^{41}$ and prioritised procedures. ${ }^{42}$ The Directive contains an exhaustive list of ten situations in which acceleration of the examination of the request is possible. For example, in situations such as the asylum seeker has misled the authorities by presenting false documents, or destroyed document, comes from a safe country or in case of a subsequent application or an application just to delay his removal, the chance that an application will be awarded is very small. ${ }^{43}$ The Directive does not provide time limits for these accelerated procedures. A study by the European Council of Refugees and Exiles (ECRE) shows that accelerated procedures were applied in seven Member States in 2016. The percentage of applications handled in the accelerated procedure varies between $2 \%$ in Poland to $38.8 \%$ in France. Prioritising is allowed in particular 'where the application is likely to be wellfounded' or 'where the applicant is vulnerable'. ${ }^{44}$ The normative distinction between prioritised and accelerated procedures is explained in the preamble of the Directive. Prioritising means shortening the overall duration by 'examining it before other, previously made applications, without derogating from normally applicable procedural time limits, principles and guarantees' ${ }^{45}$ On the other hand, acceleration is described as

introducing shorter, but reasonable, time limits for certain procedural steps, without prejudice to an adequate and complete examination being carried out and to the applicant's effective access to basic principles and guarantees provided. ${ }^{46}$

The shortest time limits are laid down in the VC for the application of a Schengen visa for a visit of maximum three months to the EU. In the current regulation, the standard time limit is only fifteen days. This period can be extended to thirty days or, as an exception, to sixty days. The VC was recently amended. ${ }^{47} \mathrm{~A}$ remarkable feature of the amended VC from the perspective of welcoming or restricting migration, in the words of Peers, is 'the power to punish countries that do not cooperate with the EU on readmission, amongst other measures

40. Art. 31 Directive 2013/32/EU. A further, substantive, delay of the total duration of an assessment of an asylum application on the merits can occur in situations where the responsibility for the asylum application is to be determined based on the criteria of the Dublin Regulation. Several time limits exist for the establishment of the responsible state and the actual transfer of the asylum applicant to the other state. The actual examination of the application on the merits will only start after the transfer of the applicant.

41. Art. 31(8) Directive 2013/32/EU

42. Art. 31(7) Directive 2013/32/EU

43. ECRE (2017) Accelerated, prioritised and fast-track asylum procedures. Legal frameworks and practice in Europe, p. 3.

44. Art. 31(7) Directive 2013/32/EU.

45. Preamble 19 Directive 2013/32/EU.

46. Preamble 20 Directive 2013/32/EU.

47. Regulation (EU) $2019 / 1155$ of the European Parliament and of the Council of 20 June 2019 amending Regulation (EC) No 810/2009 establishing a Community Code on Visas (Visa Code), pp. 25-54. by slowing down processing times' ${ }^{48}$ If the given time limits are not met, none of the EU Directives provide for consequences in the event of a late decision. ${ }^{49}$ The FRD and the BCD state that consequences of a late decision are to be determined by national law. The other Directives contain no reference at all as to what should happen if Member States fail to meet the time limits for dealing with an application. In Belgium, applicants for family reunification were granted a residence right automatically if the authorities didn't take a decision within the prescribed decision period of six months. The European Court of Justice (ECJ) considered this national practice a violation of the FRD because authorities are required to establish the existence of family relations before they authorise family reunification. ${ }^{50}$ In the case of EU citizens and their accompanying family members, a totally different picture emerges. As the residence rights enshrined in the FMD are declaratory, there is no application procedure to assess a residence right with corresponding time limits. EU citizens and their family members can reside legally on the territory of another EU Member State if, and as long as, they fulfil the conditions for residence listed in the FMD. EU citizens, as well as their family members, are obliged to register with the relevant authorities for a stay exceeding a period of three months. The period for both EU citizens and their family members within which this registration obligation must be fulfilled cannot be shorter than three months. 51 'Immediately' after registering, EU citizens are given a declaration of registration; their (TCN) family members have to apply for a residence card and receive a declaration of making this request 'immediately'. However, the period to assess the request for this residence card for TCN family members is six months. ${ }^{52}$

\subsection{Waiting Period}

A further delay for the possibility of family migration of TCNs is installing a waiting period before enabling to file an application for family reunification. Member States have the option to apply a waiting period of no longer than two years of lawful stay in the host state before the sponsor can be united with his or her family members. ${ }^{53}$ For Member States that applied a quota system at the moment of adoption of the FRD, this could be a waiting period of three years. The ECJ decided that this waiting period can't be applied automatically without taking into account all relevant factors. ${ }^{54}$ In this respect, family members of Blue Card holders, ICT

48. Peers S. (2019) The Revised EU Visa Code: Controlling EU Borders from a Distance, EU Law Analyses, 17 April 2019.

49. The time limits of the Dublin code for the different steps in the process of establishing the responsible state do attach legal consequences to exceeding these time limits.

50. ECJ 20 November 2019, C-706/18 (X), ECLI:EU:C:2019:993, paras. 34-38.

51. Arts. 8(2) and 9(2) Directive 2004/38/EU

52. Art. 10(1) FMD Directive 2004/38/EU.

53. Art. 8 Directive 2003/86/EC

54. ECJ 27 June 2006, C-540/03 (Commission v. Parliament), para. 99-100. 
workers and researchers are treated more favourably as the waiting period of Article $8 \mathrm{FRD}$ is not applicable for family reunification with these categories of migrants. ${ }^{55}$

\subsection{Time Frames in Application Procedures and Preferential Treatment}

The short(er) time frames for Schengen visa applications and applications for economic and knowledge migration are in line with the hypothesis that for these desired categories of migrants short(er) time limits would be applied. The amendment in the new VC underlines the argument that TCN Schengen visa migrants are only welcome as long as they abide by the conditions for their stay. Also the immediate provision of a residence card after registration to EU citizens confirms the hypothesis. The relatively long period to assess the request for a residence card for TCN family members is in this respect a bit surprising. A possible explanation can be that this concerns purely an administrative requirement and doesn't hinder the right of free movement of EU citizens. The long application procedures for family migrants and asylum seekers and the option of a waiting period for family migrants underline that these migrants are less welcome. These categories of migrants clearly don't get priority. For family members of the desired economic and knowledge migrants, shorter time frames and no waiting period apply. It is interesting to note that in regard to asylum applications as well shorter time frames can be applied for the well-founded applications - to whom the EU is open - as for the unfounded applications. For this last category fast procedures can be explained by the fact that these asylum seekers are already present at the territory of the EU. Fast procedures in this situation can be regarded as restrictive.

\section{Temporary Residence}

For most knowledge-related and economic-related residence purposes, it is assumed by the EU legislature that the residence is of a temporary nature. The idea that work-related migration is of a temporary nature was also mainstream in the 1950 s to early 1970 s when several European countries expanded their workforce by enabling and recruiting workers from other countries. ${ }^{56}$ However, the enactment of more restrictive migration policies in the 1970s is considered to be one of the causes of permanent settlement of many labour migrants. ${ }^{57}$ To avoid the same pitfall, in all EU migration instruments designed to regulate migration for a certain purpose of TCNs to one of the EU Member
States, the initial residence right a TCN can acquire is temporary residence. The length of initial residence, the possibility to renew the residence and the total possible length of stay differ considerably. For several residence types, the duration of residence is related to the more or less temporal nature of the residence purpose. The shortest period of residence applies to the Schengen visa, with a maximum period of residence of three months and hardly any possibility to prolong this period. Residence categories such as school pupil exchange, au pairs, trainees and volunteer programmes are also designed to be temporal by nature. In the RSD the duration of residence is defined for each of these categories. In the case of trainees, the initial duration is six months and for the rest of the residence categories the initial residence duration is one year, unless the contract or programme which determines the residence foresees a shorter duration. When it comes to students, Member States can 'determine that the total duration of residence of students does not exceed the maximum duration of studies, as provided for in national law'. ${ }^{58}$ The temporary character of seasonal work is underlined in the preamble: ${ }^{59}$

The maximum duration of stay should be fixed by Member States and limited to a period of between five and nine months which, together with the definition of seasonal work, should ensure that the work is of genuinely seasonal nature.

Furthermore, intra-corporate transfers constitute temporary migration. The maximum duration of one transfer to the Union is three years for managers and specialists, and one year for trainee employees. After this period, the intra-corporate transferee should leave the EU unless they have obtained a residence permit on another basis. ${ }^{60}$ The BCDs are more favourable in this respect. Although this Directive states that Member States can define the period of validity of the residence card to between one and four years, the residence right can be prolonged beyond this period, as follows from the more favourable treatment of holders of a Blue Card in regard to the acquisition of a long-term residence permit. ${ }^{61}$ For researchers and students, the RSD provides for the right to stay after completion of their research or studies for the purpose of job searching or entrepreneurship. ${ }^{62}$ This is an improvement of their rights in comparison with the rights of researchers and students in the directives which were replaced by the current directive. ${ }^{63}$ However, according to the preamble, this right does not automatically include a right of access to the labour market.
55. See Art. 15(2) Directive 2009/50/EC, Art. 19(2) Directive 2014/66/EU and Art. 26(1) Directive 2016/801/EU.

56. Castles S. (1986) The Guest Worker in Western Europe: An Obituary, The International Migration Review, Volume 20, Issue 4, pp. 761-78. See also CDMG (1996) Temporary Migration for Employment and Training Purposes.

57. Wiesbrock A. (2009) Legal migration to the European Union. Ten Years after Tampere. Nijmegen: Wolf Legal Publishers, p. 30.
58. See preamble 19 Directive 2016/801/EU

59. See preamble 31 Directive 2016/801/EU

60. See preamble 17 Directive 2014/66/EU.

61. Art. 16 Directive 2009/50/EC.

62. Art. 25 Directive 2016/801/EU.

63. See respectively Directive 2005/71/EC for researchers and Directive 2004/114/EC for students. 
Residence as a family member or as a refugee or otherwise protected person can be temporal, as the family relationship can end or the situation in the country of origin can change, but it is not defined as a temporary stay in the respective Directives. The same applies for EU citizens residing in another Member State. As long as the conditions for residence are fulfilled, the right to residence exists. The FMD does not contain a presumption of temporary stay.

\subsection{Temporary Residence in Light of Desired and Less Desired Migrants}

In regard to temporary stay, it appears the desirability of migrants changes. Some migrants who are admitted for work, economic or exchange purposes are only welcome on a temporary basis. Apparently, the EU legislator wanted to create a system which gives Member States control over the duration of certain residence types. However for the high-skilled and knowledge migrants Member States can or even shall grant prolonged residence rights. This underlines the desirability of these categories of migrants. The option to restrict access to the labour market underlines that these migrants are welcome as long as they fit the profile of high-skilled or knowledge migrant.

For EU citizens and their family members the non-temporary character of their right to residence is in conformity with their status of desired migrants. For the other categories of TCNs, beneficiaries of international protection and family migrants, it follows from the purpose of their stay itself: their residence right is not regarded as temporal.

\section{Duration of Residence as a Requirement for Stronger Residence Entitlements}

Under EU law, Member States are still free to design national policies to attract certain types of migrants. State practice shows a wide use of shortening time frames for stronger rights for preferred categories of migrants, so-called golden visa or even golden passport schemes. The European Commission (EC) is critical about these programmes. ${ }^{64}$ According to the EC, these schemes are of a common EU interest because they can pose serious security issues (the right to travel in the EU, money laundering, corruption). However, at this moment the EU has no competence in the field of these investor programmes. In EU migration law, time frames are used in different ways to become eligible for certain residence entitlements.

64. See: https://ec.europa.eu/home-affairs/news/20190123_commissionreports-risks-investor-citizenship-residence-schemes-eu_en. As this article is focused on EU law, these national rules and regulations are not further discussed.
First, family members of a TCN sponsor or EU citizen can claim entitlements to an autonomous right of residence, independent from the right of the family member after several years. TCN family migrants get a residence right based on their family relationship with a sponsor in one of the EU Member States. However, after five years at the latest, the spouse, unmarried partner and children who have reached the age of majority are entitled to an autonomous residence permit. ${ }^{65}$ If the family bonds are broken after the acquisition of this autonomous residence right, this will have no consequence for the residence right of the (former) family members of the sponsor. ${ }^{66}$ In regard to TCN family members of EU citizens, the FMD contains several time limits for the retention of the right of residence of these family members in case of death (one year), departure of the EU sponsor (no time limit if a child is enrolled in an educational institution) or in situations of divorce or termination of (registered) partnership (three years of marriage and one year stay in the host state). ${ }^{67}$ According to the preamble, this more favourable treatment in some of these situations follows from respect for family life and human dignity. ${ }^{68}$ The second way in which stronger residence rights are awarded to migrants after a certain period of residence is a right to permanent residence. The LTRD defines the conditions for the right to permanent residence for TCNs with five years of legal and continuous residence in the Member State concerned. Migrants with a residence right of a temporary nature at the moment of application are excluded from the scope and temporal residence does not count for the period of five years of legal stay. Although the LTRD does not contain a list of types of residence of a temporary nature, one can assume that seasonal workers, au pairs, trainees, school pupils, volunteers, students and intracorporate transferees are all excluded from the right to a permanent residence. If students have acquired another residence permit which makes them eligible for longterm residence, only half of the periods of residence for study purposes or vocational training may be taken into account in the calculation of the period of five years. ${ }^{69}$ Furthermore, Member States are allowed to only take into account half of the period of residence awaiting the decision on an application for international protection. ${ }^{70}$ Some Member States used the possibility to exclude migrants who have been admitted solely on temporary grounds from the scope of the LTRD to restrict stronger residence entitlements of certain categories of migrants. According to the EC, this loophole to restrict the scope of the LTRD has been applied in a very broad

65. Art. 15(1) Directive 2003/86/EC.

66. In case of divorce, separation or death of the sponsor, Member States may grant an autonomous residence right (Art. 15(3)). This option is not limited in time.

67. See Arts. 12 and 13 Directive 2004/38/EC. EU family members have an independent right to stay in their capacity of EU citizens, as long as they fulfil the criteria of Art. 7 of the Directive.

68. Preamble 15 Directive 2004/38/EC

69. Art. 4(2) Directive 2003/109/EC.

70. Art. 3(b) Directive 2011/51/EU amending Art. 4(2) Directive 2003/109/EC. 
reading by some Member States. ${ }^{71}$ The ECJ has ruled that a state's practice of excluding a TCN from the scope of the Directive by labelling a certain category of residence as temporary, while the residence in itself, or the intention of the migrants to stay, is not temporary, is not in accordance with the meaning of the Directive. ${ }^{72}$ In the case of EU citizens and their family members, the period to become eligible for a permanent residence right is also five years. ${ }^{73}$ The FMD does not contain any other condition than prior legal stay based on the Directive.

\subsection{Duration of Residence and Desired or Less Desired Migrants}

TCN family members are entitled to an autonomous right of residence after five years of residence. Apparently, after these migrants have been accepted and resided in the host state for several years, other motivations for a preferential treatment become important. According to the preamble, an independent residence right contributes to the integration of family members. ${ }^{74}$ Integration serves to promote economic and social stability. $^{75}$

It is striking that the period for granting a right of permanent residence for EU citizens as well as TCNs has been set at five years. ${ }^{76}$ Family migrants and beneficiaries of international protection are in principle eligible for long-term residence. Although these categories were considered less preferred before admission, after several years of residence they are treated more favourably in regard to stronger residence entitlements. However, some other categories of TCN migrants are excluded or treated less favourably. Residence of a temporary character is excluded from the scope. ${ }^{77}$ Furthermore, the time that counts for the period of five years of residence is not taken into consideration for all residence categories. This excludes or disadvantages some categories of migrants who were considered as desired at the moment of admission.

\section{Length of Stay as Protection Against Loss of Residence Right}

One of the characteristics of nationality is the right to stay on the territory of one's nationality. For migrants,

71. Report from the Commission to the European Parliament and the Council on the implementation of Directive 2003/109/EC concerning the status of TCNs who are long-term residents, $\operatorname{COM}(2019) 161$ final, p. 2.

72. ECJ 18 October 2012, C-502/10 (Singh), ECLI:EU:C:2012:636.

73. Art. 16 Directive 2004/38/EC.

74. Preamble 15 Directive 2003/86/EC

75. Preamble 4 Directive 2003/86/EC.

76. Stronks 2017, p. 142

77. The intention or preference of the migrant can be different from the legal categorisation as temporary. See also Stronks 2017, pp. 44-47 and Wickramasekara P. (2011) Circular Migration: A Triple Win or a Dead End, Global Union Research Network, ILO, p. 23.

who are residing on the territory of a state other than the state of their nationality, the right to stay is always more or less conditional. In national migration law systems, and also in EU migration law, a residence right can be revoked. For the temporal residence rights, a general ground for losing a right of residence is that the conditions for granting this right are no longer fulfilled. For example, a student who has a residence permit for study, who no longer studies or who does not have sufficient financial resources will lose his residence right. ${ }^{78}$ The residence right of a refugee, who no longer fulfils the criteria for being a refugee, can also be revoked. ${ }^{79}$ In this respect, Blue Card holders are treated more favourably if they lose their job before the validity of their residence right expires. They get a period of three months to find another employment which fulfils the criteria of the BCD. ${ }^{80} \mathrm{EU}$ citizens and their family members retain a right of residence as long as they fulfil the criteria. ${ }^{81}$ However, for workers and self-employed persons the Directive contains special provisions in case of loss of employment. ${ }^{82}$ According to the respective EU directives, the length of stay of the migrant who no longer fulfils the conditions for his residence purpose is not a factor to be taken into account by the authorities when considering the possible revocation of a residence right. In regard to TCNs, the only exception to this rule is listed in the FRD. According to Article 17, which is based on the case law of the European Court of Human Rights (ECtHR) in regard to Article $8 \mathrm{ECHR}$, several factors must be taken into account including the length of stay in the guest country. An example of the reference to Article 17 FRD and the meaning of the duration of stay can be found in a case about the revocation of the residence permits of a Chinese family, more than twelve years after issuing these permits. ${ }^{83}$ Because the father used false documents in the application for his residence permit, the residence permits were withdrawn with retroactive effect. The ECJ concluded that the FRD allows for the withdrawal, even after such a long time, but that an individual assessment must be made. The Member State should take due account of all relevant factors listed in Article 17 FRD such as the duration of residence and the ties developed with the host country and ties with the home country.

Another ground regularly applied for withdrawing a residence right is being a threat to public order and/or safety. This ground can be applied not only for family migrants ${ }^{84}$ but also for long-term residents ${ }^{85}$ and EU citizens and their family members. ${ }^{86}$ The protection

78 lands), ECLI:EU:C:2019:203. Zie ook: Boeles P. (2019) Wat is de ruimte
voor intrekking van verblijfsvergunningen met terugwerkende kracht? Asiel \& Migrantenrecht, Issue 3, pp. 96-109

84. Art. 6 Directive 2003/86/EC

85. Arts. 9 and 112 Directive 2003/109/EC

86. Arts. 27 and 28 Directive 2004/38/EC. 
against withdrawal of a residence right for family members must be deduced from the general provision that in any decision several factors must be taken into account. ${ }^{87}$ One of these factors is the time spent in the host country and the home country. For long-term residents, more or less the same factors listed in Article 17 FRD are also mentioned in Article 12 LTRD. Also for this category of migrants, the duration of stay in the host country is one of these factors.

For EU citizens and their family members who fall within the scope of the FMD, the same mechanism applies: the longer their stay in the host Member State, the stronger their protection against expulsion. The general ground for expulsion is laid down in Article 27 FMD. Article 28 contains a system of protection based on the duration of residence. The longer the residence, the stronger the protection. However, the importance of duration of residence for the protection against expulsion has been limited by the Court of Justice. The ECJ concluded that the period of ten years of lawful residence, which offers the strongest protection, must be counted backwards from the moment the expulsion measure is taken. ${ }^{88}$ Furthermore, the Court decided that time spent in prison will interrupt the period of lawful residence. However, ten years of residence prior to imprisonment 'may be taken into consideration as part of the assessment to determine whether the integrating links previously forged with the host Member State have been broken'. ${ }^{89}$ In above-mentioned situations, the danger to society that emanates from a migrant must be balanced against other factors, among which is the duration of residence. For this balancing exercise, the case law of the ECtHR is of great importance. However, in the case law of the ECtHR a tendency can be discerned where less weight is attached to the length of stay in the host country in the case of expulsion on the grounds of a criminal conviction. ${ }^{90}$

\subsection{Protection Against Expulsion and Desirability}

Duration of residence is one of the factors to be taken into account in case of expulsion of family migrants, long-term residents and EU citizens and their family members. For migrants who reside on a residence right with a fixed duration - except for family migrants - the respective directives don't provide for a stronger protection in relation to the duration of residence. In situations where the migrant no longer fulfils the criteria of the purpose of residence, this makes sense. The desirability of a migrant depends to a large extent on his purpose of residence. After five years of residence and acquisition of a permanent right to residence, the initial residence purpose becomes less important. Protection against loss of residence and expulsion is based on other factors like duration of residence and probable conse-

87. Art. 17 Directive 2003/86/EC.

88. ECJ 16 January 2014, C-400/12 (M.G.) ECLI:EU:C:2014:9.

89. Ibid, para. 38.

90. Klaassen M.A.K., Lodder G.G. (2017) Kroniek gezinshereniging 2016-2017, Asiel \& Migrantenrecht, Issue 10, pp. 479-89. quences of this residence like stronger bonds with the host state and weakening ties with the home state. However, state practice shows that by committing crime or fraud, migrants with even very long duration of residence can turn as undesired migrants.

\section{Conclusion}

In this contribution, I provide an overview of the way time is used by the EU legislature in the context of developing policies to attract or restrict residence of certain categories of migrants. The length of application procedures, the temporary character, right to stronger entitlements based on duration of residence and protection against expulsion in relation to duration of stay are compared for different categories of migrants. The starting hypothesis is that time would be used in a more favourable way for desired migrants. EU citizens and TCN economic-related and knowledge-related categories of migrants are considered as more desired categories of migrants.

For the time frames for application procedures, the hypothesis is confirmed. The analyses of the respective rules for EU citizens and TCNs do indeed show a preferential treatment of the more desired categories in respect of short(er) time frames. As the residence right of EU citizens is declaratory, they do not have to apply for a residence right and they will receive a declaration of residence immediately. However, the time frame for assessing the right to residence for TCN family members of EU citizens is relatively long: six months. This is a bit surprising from the perspective of favourable treatment of EU citizens and their family members. Economic- and knowledge-related TCN migrants can be distinguished by relatively short time limits for processing an application. The EU legislature even found it worthwhile to enlist the option of shorter decision periods for researchers, volunteers and ICT workers, although Member States are always free to have their own shorter national time limits than the EU legislature prescribes. This underlines the importance attached to making these types of migration attractive. On the other hand, in the case of less desired family migration (apart from family members of economic migrants) substantially longer decision periods apply. The same applies for asylum seekers. However, as well for the more welcome category of well-founded applicants as for the undesired category of probably unfounded applicants, shorter time frames can be applied. Finally, for family migrants the time before being eligible for family reunification can be substantially prolonged, by implementing a waiting period of lawful residence of the sponsor. Also, this waiting period doesn't apply for family members of the more welcome Blue Card holders and researchers.

When it comes to the use of time in respect of temporary stay, entitlements based on duration of residence and protection against loss of residence or expulsion, a dif- 
ferent picture emerges. We can still see a favourable treatment of EU citizens and their family members. Their residence is not considered temporary. They can stay as long as they fulfil the criteria. Furthermore, they are entitled to a stronger residence entitlement after five years. This also applies to family migrants and accepted asylum seekers. As the purpose of residence is in principle not temporary, the right of residence is not considered temporary. Also these migrants can be granted stronger residence rights after five years. In respect of the period for being eligible for stronger rights, there is no longer a distinction between EU citizens and TCN migrants. However, the possibility not to take into account part of the time awaiting a decision on the asylum application for the calculation of five years' residence for the acquisition of a long-term resident permit is a reminder of a less welcoming policy for accepted asylum seekers.

Residence based on economic- and knowledge-related purposes is in principle considered temporary, with an exception for Blue Card holders. In the revised directive for researches and students the EU legislator created an option for continuation of residence after completion of the research or studies. This is an improvement in respect of developing welcoming policies for these categories of migrants. For the acquisition of a permanent right to stay, migrants with a temporary right of residence are excluded. This applies to most categories of economic- and knowledge-related migration, except for Blue Card holders. Furthermore, for students who acquired a non-temporary right of residence after completion of their studies, only half of their time as student can be taken into account for the acquisition of a longterm residence right. It appears that after welcoming the economic and knowledge migrants, the EU legislator is careful in granting these categories stronger entitlements.

After the acquisition of an autonomous or permanent residence right, the original distinction between desired and less desired categories of migrants based on the purpose of stay is even smaller. Instead, duration of stay and ties developed during this residence become more important for protection against expulsion. 